\title{
A Novel Serum-Free Method for Culturing Human Prenatal Retinal Pigment Epithelial Cells
}

\author{
David M. Gamm, ${ }^{1,2}$ J. Nicholas Melvan, ${ }^{1}$ Rebecca L. Shearer,${ }^{1}$ Isabel Pinilla, ${ }^{3}$ \\ Grzegorz Sabat, ${ }^{4}$ Clive N. Svendsen, ${ }^{1,5}$ and Lynda S. Wright ${ }^{1}$
}

\begin{abstract}
Purpose. Established techniques for culturing primary human retinal pigment epithelial (RPE) cells have facilitated the laboratory investigation of this multipurpose retinal cell layer. However, most culture methods involve the use of animal serum to establish and maintain RPE monolayers, which can complicate efforts to define and study factors involved in the maturation and function of these cells. Therefore, this study was conducted to develop a simple, serum-free system to propagate and sustain human RPE in vitro.
\end{abstract}

Methods. RPE was dissected from human prenatal donor eyes and cultured in serum-free defined medium containing the commercially formulated supplement B27 or N2. Cultures were grown initially as adherent tissue sections or suspended spherical aggregates and later expanded and maintained as monolayers. PCR, Western blot analysis, and immunocytochemistry were used to monitor gene and protein expression in established cultures, followed by examination of secretory products in RPE conditioned medium by ELISA and mass spectrometric analysis.

Results. In medium supplemented with B27, but not N2, RPE could be expanded up to 40,000-fold over six passages and maintained in culture for more than 1 year. In long-term cultures, typical cellular morphology and pigmentation were observed, along with expression of characteristic RPE markers. RPE monolayers also retained proper apical-basal orientation and secreted multiple factors implicated in the maintenance of photoreceptor health and the pathogenesis of age-related macular degeneration.

Concuusions. Monolayer cultures of human prenatal RPE can be grown and maintained long term in the total absence of serum and still retain the phenotype, gene and protein expression profile, and secretory capacity exhibited by mature RPE cells.

From the ${ }^{1}$ Waisman Center, and the Departments of ${ }^{2}$ Ophthalmology and Visual Sciences, ${ }^{5}$ Anatomy and Neurology, and ${ }^{4}$ Genetics/ Biotechnology Center, University of Wisconsin School of Medicine and Public Health, Madison, Wisconsin; and the ${ }^{3}$ Department of Ophthalmology, Miguel Servet University Hospital and Aragones de Ciencias de la Salud, Zaragoza, Spain.

Supported by National Eye Institute Grant K08EY015138, the Walsh Foundation, Lincy Foundation, the Foundation Fighting Blindness, the Retina Research Foundation, the Kinetics Foundation, the U.S. Department of Defense (CNS), and Instituto Aragones de Ciencias de la Salud (IP). DMG is a recipient of a Research To Prevent Blindness Robert E. McCormick Scholar Award.

Submitted for publication June 23, 2007; revised October 2 and 30, 2007; accepted December 14, 2007.

Disclosure: D.M. Gamm, None; J.N. Melvan, None; R.L. Shearer, None; I. Pinilla, None; G. Sabat, None; C.N. Svendsen, None; L.S. Wright, None

The publication costs of this article were defrayed in part by page charge payment. This article must therefore be marked "advertisement" in accordance with 18 U.S.C. $\$ 1734$ solely to indicate this fact.

Corresponding author: David M. Gamm, Department of Ophthalmology and Visual Sciences, University of Wisconsin School of Medicine and Public Health, T607 Waisman Center, 1500 Highland Avenue, Madison, WI 53705; dgamm@wisc.edu.
(Invest Ophthalmol Vis Sci. 2008;49:788-799) DOI:10.1167/ iovs.07-0777

he homogenous, relatively nondescript appearance of RPE 1 on the light microscopic level belies a complex cellular organization and function that is critical for the preservation of outer retinal health and activity. ${ }^{1}$ In addition, mounting evidence points to an important role for the RPE in the development of the neurosensory retina. ${ }^{2,3}$ The study of the RPE has been aided by advancements in culture techniques that encourage the adoption of characteristic RPE properties found in vivo. Such properties include, among others, formation of a pigmented, compact monolayer of polygonal cells connected by tight junctions, expression of specialized proteins, preservation of cellular orientation, and an ability to secrete multiple factors. ${ }^{4-11}$ However, the demonstration of some or all of these features in vitro has necessitated the use of animal serum and/or intricate combinations of chemical and protein constituents not available in prefabricated media supplements.

The presence of serum in cell culture medium can be problematic, because it contains numerous partially characterized or undefined factors that vary in concentration between commercial preparations. ${ }^{7,12-15}$ The existence of a defined, serum-free growth and maintenance medium would be of particular value for the straightforward identification of factors released by the RPE in vitro. It would also provide a simplified, reproducible environment for studying the maturation and physiology of the RPE layer and its response to pharmacologic treatments. Last, it would facilitate the use of cultured human RPE in clinical studies by reducing exposure of cells to animal products before transplant. Some protocols allow for the reduction or removal of serum from RPE medium preparations after initial attachment or once the cells reach confluence. ${ }^{16-19}$ However, this practice may alter cell survival and function and does not eliminate the exposure of proliferating RPE cell populations to serum. ${ }^{14,20}$ To address this problem, Tezel and Del Priore $^{12}$ developed a chemically defined, serum-free medium that supported the initial attachment and growth to confluence of adult human RPE cells. However, production of the customized serum-free medium required the separate addition of numerous components and did not use commercially formulated supplements. Furthermore, the cultured RPE cells underwent limited characterization in vitro. Thus, the impact of the serumfree environment on the expression of critical RPE proteins remained unknown.

Sources of human RPE for experimentation and clinical use have grown to include primary prenatal ${ }^{6,8,17,21}$ and postna$\mathrm{tal}^{7,12,22,23}$ tissue, transformed cell lines, ${ }^{24-27}$ and embryonic stem (ES) cells. ${ }^{28}$ These sources differ widely in their expansion potential, degree of differentiation, and propensity to display RPE-like characteristics. For example, the commonly used ARPE-19 cell line can be passaged indefinitely but does not remain pigmented or reliably express certain RPE-selective proteins, such as bestrophin. ${ }^{9,27,28}$ Postnatal human RPE, on the other hand, has limited expansion potential, but retains a relatively mature phenotype in culture. ${ }^{7,12}$ Human ES cells are theoretically in limitless supply and can produce cells with a 
gene and protein expression pattern and appearance similar to primary RPE cultures with little contamination from other cell types. ${ }^{28}$ However, the functional competence of ES cell-derived RPE is yet to be established ${ }^{29}$ and, similar to other sources of RPE, they are grown in the presence of serum. Cultures of primary human prenatal RPE have the benefit of possessing a greater growth capacity than adult RPE while still exhibiting many of the known features of mature RPE in vitro. $^{6,17}$ There are also disadvantages to the culture of human prenatal RPE, including supply limitations and ethical concerns regarding its use.

With these issues in mind, we sought to develop a simple, serum-free method for culturing human prenatal RPE by using commercially formulated medium supplements. B27, a supplement that contains numerous factors of potential importance for RPE growth and maturation, ${ }^{6,8,12,18,30}$ supported the adherence, propagation, and passaging of RPE on laminin-coated tissue culture plastic. In contrast, RPE cultures exhibited minimal expansion in the presence of $\mathrm{N} 2$ supplement, which includes only a fraction of the components present in B27.30,31 Primary attachment and outgrowth of RPE cells was improved by implementing a method in which explants were cultured initially as suspended spheroids. Resulting pigmented spheroids consistently adhered to laminin-coated tissue culture plastic and produced high yields of RPE cells. The morphology, gene and protein expression profile, polarity, and secretory capacity of cells cultured in this manner were similar to that reported for RPE grown in the presence of serum. ${ }^{6,11}$

\section{Methods}

\section{Serum-Free RPE Monolayer Culture}

RPE was isolated from human eyes between 10 and 16 weeks of gestation according to protocols approved by the NIH, the Institutional Review Board at the University of Wisconsin-Madison, and the University of Washington. Eyes were shipped from the University of Washington Birth Defects Laboratory overnight at $4^{\circ} \mathrm{C}$ in sterile-filtered transport medium $\left(30 \mathrm{mM} \mathrm{KCl}, 5 \mathrm{mM}\right.$ glucose, $0.24 \mathrm{mM} \mathrm{MgCl}_{2}, 1.95$ $\mathrm{mM} \mathrm{NaH}{ }_{2} \mathrm{PO}_{4} \cdot 6 \mathrm{H}_{2} \mathrm{O}, 20 \mathrm{mM} \mathrm{Na} 2 \mathrm{HPO}_{4} \cdot 2 \mathrm{H}_{2} \mathrm{O}$, and $20 \mathrm{mM}$ lactic acid, followed by adjustment to $\mathrm{pH} 7.2$ with $\mathrm{KOH}$ pellets and $300 \mathrm{mOsM}$ with approximately 140 millimoles sorbitol; all chemicals obtained from Sigma-Aldrich, St. Louis, MO) and dissected on arrival. Whole eyes were maintained in ice-cold dissection medium (DM; 70\% DMEM containing 4.5 g/L D-glucose (catalog no. 11965; Invitrogen, Carlsbad, CA), 30\% F12 nutrient mixture containing t-glutamine (catalog no. 11765; Invitrogen), and 1\% antibiotic-antimycotic solution (catalog no. 14240; Invitrogen), whereas the attached periocular tissues were carefully removed and discarded. The remaining intact globes were rinsed twice in DM, and the anterior segment of the eye and the vitreous were removed. The eye cup was then washed two times with DM, and the detached neural retina was removed in its entirety with forceps. If the neural retina had not spontaneously detached after removal of the vitreous, a $1-\mathrm{mL}$ syringe with a 25 -gauge, $5 / 8$-in. needle was used to irrigate with DM gently under the peripheral retina, to separate it fully from the underlying RPE. After two more DM washes, the remaining RPE and attached choroid were peeled from the underlying sclera with forceps, being careful to avoid the ciliary margin region. At this point, the RPE-choroid explants were treated in one of three ways.

Method 1: Isolated RPE Sheets. Some explants were incubated in DM containing 2\% Dispase (catalog no. 17105-041; Invitrogen) for 30 minutes at $37^{\circ} \mathrm{C}$ and washed twice in DM before small sheets of RPE were teased away from the choroid with forceps and irrigation. The isolated RPE sheets were collected and further chopped into 200- $\mu \mathrm{m}$ sections with a Mcllwain automated tissue chopper (Mickle Laboratory Engineering Co., Ltd., Guildford, UK), as described previously for primary cortical and retinal tissue. ${ }^{32,33}$ After the tissue sections were chopped, they were placed on laminin-coated $(0.001 \%$, catalog no. L2020; Sigma-Aldrich) tissue culture plastic (flasks or wells) in a minimal volume of serum-free RPE medium (SFRM), consisting of DM supplemented with either $2 \%$ B27 (50× solution, catalog no. 17504 ; Invitrogen) or $1 \%$ or $2 \%$ N2 (100× solution, catalog no. 17502 ; Invitrogen), designated SFRM-B27 or SFRM-N2, respectively.

Method 2: RPE-Choroid Explants. Alternatively, RPE-choroid explants were immediately chopped into $200-\mu \mathrm{m}$ sections without exposing them to proteolytic enzymes or manipulating them further with forceps. After examining the chopped explant sections under a dissection microscope, only those containing prominent sheets of attached RPE were subsequently placed onto laminin-coated tissue culture plastic. As described earlier, chopped explants were cultured exclusively in SFRM-B27 or SFRM-N2.

Method 3: Pigmented Spheroids. Based on observations of cell cultures established from the previous two methods, a modification of method 2 was devised in which chopped RPE- choroid explants were initially placed in suspension culture in SFRM-B27. Nonpigmented and pigmented spherical tissue aggregates formed within hours, with many partially pigmented spheroids becoming uniformly pigmented over 2 to 4 weeks in culture. At various times, darkly pigmented spheroids were removed from suspension culture by using a glass Pasteur pipette and were plated onto laminin-coated tissue culture plates in SFRM-B27 or SFRM-N2.

Regardless of the method used, all cultures were maintained at $37^{\circ} \mathrm{C}$ and $5 \% \mathrm{CO}_{2}$, and $50 \%$ to $75 \%$ of the cell culture medium was exchanged every 1 to 2 days. Within 24 to 48 hours of initial plating, expanding monolayers of RPE cells were observed to emanate from attached tissue sections or pigmented spheroids. With method 2, occasional colonies also arose that contained dense collections of discrete, multilayered choroidal fibroblasts. The contaminating colonies were marked on the outside of the flask and manually removed with a Pasteur pipette under a dissecting microscope. After approximately 4 to 7 days, the remaining tissue sections or spheroids were easily detached with simple irrigation and collected, leaving the surrounding monolayer colonies of RPE cells attached to the flasks. Detached pigmented spheroids could be replated on laminin-coated plastic at least three times with no observable decrease in initial RPE production, or stored in liquid nitrogen in serum-free, cell-freezing medium (catalog no. C6295; Sigma-Aldrich).

After removal of the tissue sections or spheroids, the remaining adherent RPE monolayer colonies were treated with cell-detachment medium (Accutase, catalog no. SCR005; Chemicon, Temecula, CA) for 10 to 15 minutes at $37^{\circ} \mathrm{C}$ until all cells had rounded up and begun to lift off the plastic. Dissociated RPE cells were harvested by gently irrigating the remaining loosely attached cells to lift them off the plastic with a glass Pasteur pipette and transferring the cell suspension to a 15-mL conical tube. After a 3-minute centrifugation at $1000 \mathrm{rpm}$, the cell detachment solution overlying the cell pellet was removed, and the cells were resuspended in $10 \mathrm{~mL}$ of SFRM-B27 or SFRM-N2. The cells were pelleted and resuspended a second time, counted on a hemocytometer, and plated on laminin-coated tissue culture plastic at a density of $\geq 50,000$ cells $/ \mathrm{cm}^{2}$. When cultures reached confluence (3-7 days after plating), they could be passaged until a growth plateau was reached, and evidence of active cell division was no longer evident by light microscopy (up to six passages). At each passage, a portion of the cells were designated for long-term observation and study or for serial passaging to establish growth curves. Excess RPE cells were stored as aliquots in liquid nitrogen after dissociation and later rethawed to establish additional cultures as needed.

\section{RPE Growth Determination}

Growth curves were obtained by serially passaging RPE cultures within 24 hours of reaching confluence and determining the total number of cells present per tissue culture flask or well using a hemocytometer and trypan blue dye exclusion. Initial cell counts at day 0 (i.e., passage 1) were obtained after dislodging and removing adherent primary tissue sections or pigmented spheroids and harvesting the surrounding 
TABLE 1. Primers Used for RT-PCR

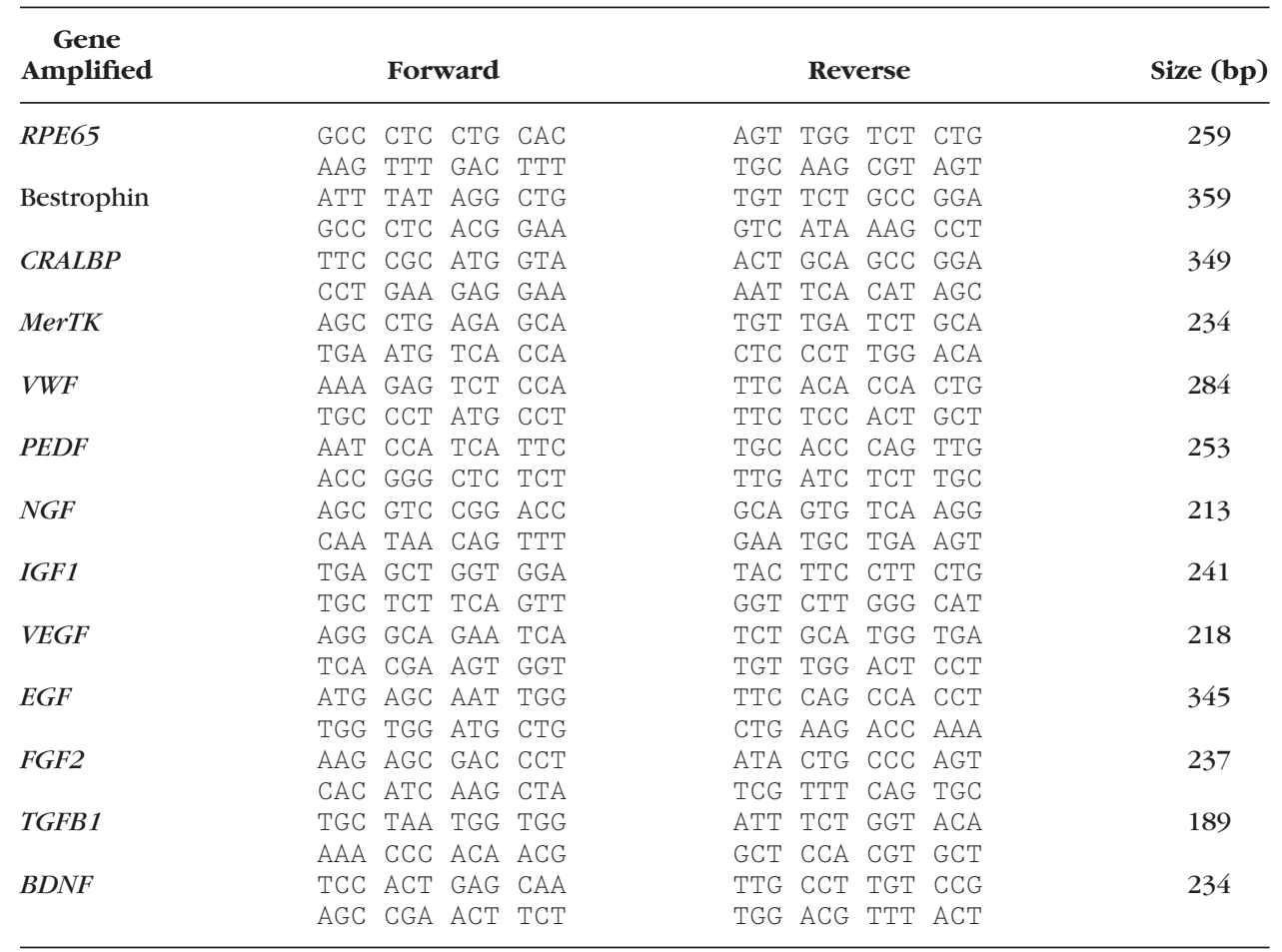

monolayer skirt of RPE cells for subsequent passage. All counts were performed in triplicate, and the mean was used to establish the increase ( $n$-fold change) in cell quantity for each passage. Doubling times were calculated from exponential growth curves plotted for each culture (Prism ver. 3.02; GraphPad Software, San Diego, CA). Cumulative cell counts at later passages were extrapolated to account for the fraction of cells stored in liquid nitrogen.

\section{BrdU Incorporation}

Acutely dissociated RPE cells from three separate cultures were plated onto poly-L-lysine (0.01\%; Sigma-Aldrich) and laminin-coated glass coverslips (50,000 cells/coverslip) and incubated in SFRM-B27, with or without 20 ng/mL FGF2 (catalog no. GF003; Chemicon). After 2 days in culture, bromodeoxyuridine (BrdU; Sigma-Aldrich) was added to the media to a final concentration of $0.2 \mu \mathrm{M}$. Twenty-four hours later, the RPE cells were fixed for 10 minutes in ice-cold methanol, washed in PBS, and prepared for immunocytochemistry.

\section{RNA Isolation and cDNA Synthesis}

Total RNA was isolated (RNeasy MiniKit; Qiagen, Valencia, CA) using the company's protocol, which included an optional DNase I treatment step. Individual RNA samples were treated a second time with amplification grade DNase I (Invitrogen) before cDNA synthesis, which was performed with a kit (Superscript III First-Strand Synthesis System for RT-PCR; Invitrogen). All reactions included control samples in which reverse transcriptase enzyme was not added to the reaction.

\section{RT-PCR}

PCR reactions were performed by combining master mix (Promega, Madison, WI), $10 \mu \mathrm{m}$ each of the appropriate forward and reverse primers (Table 1), and 1:40 diluted cDNA template. Samples were initially denatured at $95^{\circ} \mathrm{C}$ for 5 minutes followed by 35 cycles of PCR amplification $\left(95^{\circ} \mathrm{C}\right.$ for 15 seconds, $60^{\circ} \mathrm{C}$ for 30 seconds, $72^{\circ} \mathrm{C}$ for 1 minute) and a final extension at $72^{\circ} \mathrm{C}$ for 10 minutes. PCR products were visualized on a $1.5 \%$ agarose gel containing $0.1 \%$ ethidium bromide.

\section{Quantitative PCR}

Quantitative PCR was performed on a thermocycler (Opticon 2; BioRad, Hercules, CA, with SYBR Green $2 \times$ master mix; Applied Biosystems, Foster City, CA) and 300 picomoles of the following forward and reverse primers in $20-\mu \mathrm{L}$ reactions: $\beta$-actin: (forward) 5 '-GCGAGAAGATGACCCAGATC-3', (reverse) 5'-CCAGTGGTACGGCCAGAGG-3'; bestrophin: (forward) 5'-CAA GCT GCT ATA TGG CGA GTT-3', (reverse) 5'-GCC AGC CTA TAA ATA AAG CGG AT-3'. Reverse transcription reactions were diluted $1: 40$, and $4 \mu \mathrm{L}$ were used per reaction. Samples from five individual cultures were initially denatured at $95^{\circ} \mathrm{C}$ for 15 minutes followed by 40 cycles of PCR amplification $\left(95^{\circ} \mathrm{C}\right.$ for 20 seconds, $55^{\circ} \mathrm{C}$ for 30 seconds, $72^{\circ} \mathrm{C}$ for 30 seconds) with a plate reading after every extension. Melting curves were determined to confirm amplification of the expected fragment. In addition, standard curves were measured for all primer sets by serial dilution of reverse transcriptase reactions, and efficiencies were calculated to ensure that all primer sets had similar efficiencies of amplification. Each reaction was performed in triplicate and $\mathrm{C}_{\mathrm{T}}$ values were obtained by averaging the results. The relative differences ( $n$-fold) in gene expression of a characteristic marker of mature RPE, bestrophin, was determined across cultures by using $\beta$-actin as an internal control for each reaction set (to determine $\Delta \mathrm{C}_{\mathrm{T}}$ values) and arbitrarily designating one culture as a reference (to determine $\Delta \Delta \mathrm{C}_{\mathrm{T}}$ values). Data are presented as the mean relative change \pm SEM of three separate qPCR amplification reactions for each culture.

\section{Cell Lysate Preparation}

RPE cells were solubilized in modified RIPA buffer $(50 \mathrm{mM}$ Tris- $\mathrm{HCl}$ [pH 7.4], $150 \mathrm{mM} \mathrm{NaCl}, 2 \mathrm{mM}$ EDTA, 0.1\% SDS, 0.7\% Triton X-100, $0.3 \%$ Nonidet P-40, $1 \%$ deoxycholate, $1 \mathrm{mM}$ PMSF, $2 \mathrm{mM} \mathrm{NaVO}$ ) and 1:100 protease inhibitor cocktail for use with mammalian cell and tissue extracts (catalog no. P8340; Sigma-Aldrich) containing $104 \mathrm{mM}$ 4-(2-aminoethyl)benzenesulfonyl fluoride, $80 \mu \mathrm{M}$ aprotinin, $2 \mathrm{mM}$ leupeptin, $4 \mathrm{mM}$ bestatin, $1.5 \mathrm{mM}$ pepstatin $\mathrm{A}$, and $1.4 \mathrm{mM} \mathrm{E}-64$. Lysates were sonicated and total protein was quantified (DC Protein Assay; Bio-Rad). 


\section{RPE-Conditioned Medium Preparation}

Tissue culture flasks containing confluent RPE monolayers were washed three times with DM followed by a 24-hour incubation in DM. Thereafter, RPE-conditioned medium (RPE CM) was collected, and 1:200 protease inhibitor cocktail for use in tissue culture medium (catalog no. P1860; Sigma-Aldrich) was added. Conditioned medium was then concentrated (up to 80-fold) using centrifugal filter devices (Amicon; Millipore, Billerica, MA) with a 3-kDa cutoff according to the manufacturer's instructions. Total protein was then quantified (DC Protein Assay; Bio-Rad).

\section{Western Analysis}

Twenty micrograms of protein from RPE cell lysates or concentrated RPE-conditioned medium was collected from RPE monolayers. Protein samples were separated on $4 \%$ to $20 \%$ gradient Tris-Cl gels (Bio-Rad), electroblotted onto PVDF membranes and stained with Ponceau red to confirm transfer. Membranes were blocked with 5\% nonfat dry milk and $2.5 \%$ BSA in TBST for 1 hour at room temperature followed by consecutive 1 hour incubations at room temperature with primary antibody in TBST $+1.5 \%$ BSA and HRP-conjugated secondary antibody in TBST $+1 \%$ nonfat dry milk. Primary antibodies used for Western blot analysis were directed against RPE65 (mouse monoclonal, 1:2000; Chemicon), bestrophin (mouse monoclonal, 1:500; Chemicon), CRALBP (mouse monoclonal, 1:50,000, gift of John Saari, University of Washington, Seattle), ezrin (rabbit polyclonal, 1:1000; Cell Signaling Technologies, Danvers, MA), occludin (rabbit polyclonal, 1:250; Zymed, Carlsbad, CA), claudin-10 (rabbit polyclonal, 1:250; Zymed), PEDF (mouse monoclonal, 1:500; Chemicon), VEGF (rabbit polyclonal, 1:200, Santa Cruz Biotechnology, Santa Cruz, CA), and FGF2 (mouse monoclonal, 1:500; Upstate Biotechnology, Charlottesville, VA). Protein bands were visualized by chemiluminescence (ECL or ECL Plus Western Blot Analysis Detection Kit; GE Healthcare, Chalfont St. Giles, UK).

\section{Enzyme-Linked Immunosorbent Assay}

During routine passaging of RPE cultures, $10^{6}$ cells were plated into each laminin-coated well of a six-well plate in SFRM-B27. Cultures were maintained with daily medium exchange for 4 to 6 weeks until cultures displayed mature RPE cell morphology and pigmentation. Cultures were then washed three times with DM followed by a 24-hour incubation in SFRM-B27. Thereafter, RPE CM was collected and 1:200 protease inhibitor cocktail (catalog no. P1860; Sigma-Aldrich) was added. Conditioned medium was then concentrated threefold with the centrifugal filter devices (Amicon Centriplus; Millipore) with a 3-kDa cutoff according to the manufacturer's instructions. Levels of VEGF and FGF2 protein were quantified in triplicate by ELISA (R\&D Systems, Minneapolis, MN) using the manufacturer's protocols. PEDF levels were similarly quantified by ELISA (Chemicon), with the exception that the concentrated RPE CM was first treated with urea, per the manufacturer's protocol. The plated RPE cells from each well were then dissociated and counted by using a hemocytometer to express results as nanograms of growth factor produced per day per million cells (mean \pm SEM). A minimum of three assays were performed for each growth factor.

\section{Immunocytochemistry}

During routine passaging of proliferating RPE cultures, 30,000 to 50,000 cells were plated in SFRM-B27 onto poly-L-lysine and laminincoated glass coverslips in 24-well plates. Cultures were maintained in SFRM-B27 with daily medium exchange for 4 to 8 weeks until cultures displayed mature RPE cell morphology and pigmentation. Cells were fixed with $4 \%$ paraformaldehyde for 20 minutes and washed with phosphate-buffered saline (PBS). Fixed cell cultures were permeabilized for 10 minutes in $0.2 \%$ Triton X-100 in PBS, blocked with 5\% normal goat serum and $0.2 \%$ Triton X-100 in PBS for 30 minutes, and processed for immunocytochemistry with primary antibodies to be- strophin (1:100), CRALBP (1:2000), ezrin (1:100), occludin (1:100), RPE65 (1:100), and ZO-1 (rabbit polyclonal, 1:100, Zymed). After they were rinsed with PBS, the cells were incubated for 30 minutes with secondary antibodies conjugated to Alexa 488 or Alexa 546 (1:1000; Invitrogen-Molecular Probes, Eugene OR). Thereafter, Hoechst 33258 (1:10,000 in PBS) was added for 5 minutes to visualize nuclei, followed by mounting in antifade reagent (Prolong Gold; Invitrogen-Molecular Probes). Serial confocal image sections were collected with a laser scanning fluorescence confocal microscope (model C1; Nikon Corp., Tokyo, Japan) and the resulting imaging data were used to reconstruct cross-sectional $z$ scans and rendered volume images (EZ-C1 software; Nikon Corp.). For BrdU immunostaining, coverslips were exposed to primary antibody directed against BrdU (rat monoclonal, 1:300; Accurate Chemical, Westbury, NY), washed, and incubated with 1:2000 anti-rat secondary antibody conjugated to $\mathrm{Cy} 3$ (Jackson Laboratories, West Grove, PA), followed by Hoechst 33258. To count BrdU-positive cells, digital images of immunostained cells were taken using a highresolution camera (SPOT RT Slider; Diagnostic Instruments, Sterling Heights, MI). Five to 10 random fields $(\times 40$ magnification $)$ were counted from at least three separate coverslips per experiment. The percentage of BrdU incorporation was expressed as the mean \pm SEM for three separate experiments, and the results were analyzed using Student's two-tailed, unpaired $t$-test.

\section{Two-Dimensional Gel Electrophoresis}

Protein samples from RPE CM were concentrated to $919 \mu \mathrm{g} / \mathrm{mL}$ and mixed with five volumes of precooled $\left(-20^{\circ} \mathrm{C}\right)$ precipitation solution ( $10 \%$ trichloroacetic acid in acetone). Proteins were precipitated overnight at $-20^{\circ} \mathrm{C}$, pelleted by centrifugation for 15 minutes at $12,000 \mathrm{~g}$ $\left(4^{\circ} \mathrm{C}\right)$, washed twice with ice-cold acetone, pelleted again, and washed once more with $50 \%$ ice-cold acetone in water to remove any residual salt contamination. The pellet was dried to remove excess acetone but was prevented from completely drying, to facilitate subsequent resolubilization. The sample was reconstituted in isoelectric focusing (IEF) buffer (8 M urea, 4\% CHAPS, $40 \mathrm{mM}$ Tris-HCl [pH 9.0], $100 \mathrm{mM}$ dithiothreitol [DTT], and 0.2\% ampholyte [Bio-Lyte 3/10; Bio-Rad], with trace bromophenol blue).

For isoelectric focusing, $17 \mathrm{~cm}, \mathrm{pH} 3$ to 10 IPG strips (ReadyStrip; Bio-Rad) were rehydrated with 500 and $1200 \mu \mathrm{g}$ of protein sample overnight at room temperature. The isoelectric focusing was performed in an IEF cell (Protean; Bio-Rad) at $20^{\circ} \mathrm{C}$ with a current limit of $30 \mu \mathrm{A} / \mathrm{strip}$ for a total of $55,000 \mathrm{~V} / \mathrm{h}$ (1-hour equilibration at $250 \mathrm{~V}$, 3-hour slow ramp at $3000 \mathrm{~V}$, 4-hour slow ramp at 10,000 V, and final fast ramp at $10,000 \mathrm{~V}$ for $45 \mathrm{~V} / \mathrm{h}$ ). Focused IPG strips were stored at $-80^{\circ} \mathrm{C}$ until second-dimension analysis.

Before second-dimension analysis, the strips were equilibrated for 30 minutes in SDS equilibration solution (6 M Urea, 2\% SDS, 30\% glycerol, $50 \mathrm{mM}$ Tris-HCl [pH 8.8], with trace bromophenol blue) containing $1 \% \mathrm{wt} / \mathrm{vol}$ DTT, then transferred to SDS equilibration solution containing $2.5 \%$ IEF and incubated for an additional 30 minutes. The second dimension was performed overnight (Protean II xi system; Bio-Rad) with 1-mm-thick, precast, $8 \%$ to $16 \%$ gradient SDS polyacrylamide gels (Bio-Rad) as follows: 1-hour stacking at $25 \mathrm{~V}$ (start: $8 \mathrm{~mA}$, end: $7 \mathrm{~mA}$ ), 1-hour stacking at $50 \mathrm{~V}$ (start: $16 \mathrm{~mA}$, end: $15 \mathrm{~mA}$ ), 2-hour resolving at $100 \mathrm{~V}$ (start: $31 \mathrm{~mA}$, end: $25 \mathrm{~mA}$ ), 16-hour resolving at 80 $\mathrm{V}$ (start: $19 \mathrm{~mA}$, end: $10 \mathrm{~mA}$ ), 0.5 -hour resolving at $300 \mathrm{~V}$ (start: $40 \mathrm{~mA}$, end: $38 \mathrm{~mA}$ ).

After electrophoresis, the gels were rinsed in water, fixed for 3 hours in $\mathrm{MeOH} / \mathrm{H}_{2} \mathrm{O} / \mathrm{CH}_{3} \mathrm{COOH}$ (50\%:45\%:5\%) and stained overnight with colloidal Coomassie blue (SimplyBlue SafeStain; Invitrogen). After they were stained, the gels were washed in water three times for 30 minutes to remove any background staining, and the image was captured on a GS-800 calibrated densitometer (Bio-Rad). Spots of interest were manually excised with a scalpel and transferred to siliconized tubes for subsequent proteolytic digestion and mass spectrometric analysis. 
Table 2. Composition of B27, N2, and Customized Serum-Free Medium Supplements

\begin{tabular}{|c|c|c|c|}
\hline Component & B27 & $\mathbf{N} 2$ & $\begin{array}{c}\text { Tezel and Del } \\
\text { Priore }^{12}\end{array}$ \\
\hline Bovine serum albumin & $\mathrm{Y}$ & $\mathrm{Y}$ & $\mathrm{Y}$ \\
\hline Transferrin & $\mathrm{Y}$ & $\mathrm{Y}$ & $\mathrm{Y}$ \\
\hline Insulin & $\mathrm{Y}$ & $\mathrm{Y}$ & $\mathrm{Y}$ \\
\hline Progesterone & $\mathrm{Y}$ & $\mathrm{Y}$ & $\mathbf{N}$ \\
\hline Putrescine & $\mathrm{Y}$ & $\mathrm{Y}$ & $\mathrm{Y}$ \\
\hline Sodium selenite & $\mathrm{Y}$ & $\mathrm{Y}$ & $\mathbf{N}$ \\
\hline Biotin & $\mathrm{Y}$ & $\mathbf{N}$ & $\mathbf{N}$ \\
\hline L-Carnitine & $\mathrm{Y}$ & $\mathbf{N}$ & $\mathrm{N}$ \\
\hline Corticosteroid & $\mathrm{Y}^{*}$ & $\mathbf{N}$ & $\mathrm{Y} \dagger$ \\
\hline Ethanolamine & $\mathrm{Y}$ & $\mathbf{N}$ & $\mathbf{N}$ \\
\hline $\mathrm{D}(+)$-galactose & $\mathrm{Y}$ & $\mathbf{N}$ & $\mathbf{N}$ \\
\hline Glutathione (reduced) & $\mathrm{Y}$ & $\mathbf{N}$ & $\mathbf{N}$ \\
\hline Linolenic acid & $\mathrm{Y}$ & $\mathrm{N}$ & $\mathrm{N}$ \\
\hline Linoleic acid & $\mathrm{Y}$ & $\mathbf{N}$ & $\mathrm{Y}$ \\
\hline Vitamin A derivative & $\mathrm{Y} \ddagger$ & $\mathbf{N}$ & Y@ \\
\hline Selenium & $\mathrm{Y}$ & $\mathbf{N}$ & $\mathrm{Y}$ \\
\hline T3 (triodo-1-thyronine) & $\mathrm{Y}$ & $\mathbf{N}$ & $\mathrm{Y}$ \\
\hline DL- $\alpha$-Tocopherol (vitamin E) & $\mathrm{Y}$ & $\mathbf{N}$ & $\mathbf{N}$ \\
\hline DL- $\alpha$-tocopherol acetate & $\mathrm{Y}$ & $\mathbf{N}$ & $\mathbf{N}$ \\
\hline Catalase & $\mathrm{Y}$ & $\mathbf{N}$ & $\mathbf{N}$ \\
\hline Superoxide dismutase & $\mathrm{Y}$ & $\mathbf{N}$ & $\mathbf{N}$ \\
\hline Follicle stimulating hormone & $\mathrm{N}$ & $\mathbf{N}$ & $\mathrm{Y}$ \\
\hline Epidermal growth factor & $\mathrm{N}$ & $\mathrm{N}$ & $\mathrm{Y}$ \\
\hline Basic fibroblast growth factor & $\mathrm{N}$ & $\mathrm{N}$ & $\mathrm{Y}$ \\
\hline
\end{tabular}

* Corticosterone.

† Hydrocortisone.

‡ Retinyl acetate.

$§$ all-trans Retinoic acid.

\section{Enzymatic Digestion and Mass Spectrometric Analysis}

In gel digestion and mass spectrometric analysis were performed at the Mass Spectrometry Facility (Biotechnology Center, University of Wisconsin-Madison). Coomassie G-250 (colloidal)-stained gel pieces were destained completely in 1:1 methanol: $\mathrm{H}_{2} \mathrm{O}$ containing $100 \mathrm{mM}$ $\mathrm{NH}_{4} \mathrm{HCO}_{3}$, dehydrated once for 10 minutes in 1:1 acetonitrile (ACN): $\mathrm{H}_{2} \mathrm{O}$ with $25 \mathrm{mM} \mathrm{NH}_{4} \mathrm{HCO}_{3}$ and again for 1 minute in $100 \% \mathrm{ACN}$, and dried for 5 minutes (Speed-Vac). The dried gel pieces were rehydrated and reduced in $25 \mathrm{mM}$ DTT (in $25 \mathrm{mM} \mathrm{NH} \mathrm{HCO}_{3}$ buffer) for 30 minutes at $56^{\circ} \mathrm{C}$, alkylated with $55 \mathrm{mM}$ iodoacetamide (in $25 \mathrm{mM}$ $\mathrm{NH}_{4} \mathrm{HCO}_{3}$ buffer) in darkness at room temperature for 30 minutes, washed twice in $\mathrm{H}_{2} \mathrm{O}$ for 1 minute each, equilibrated in $25 \mathrm{mM}$ $\mathrm{NH}_{4} \mathrm{HCO}_{3}$ for 1 minute, dehydrated once for 10 minutes in 1:1 ACN: $\mathrm{H}_{2} \mathrm{O}$ containing $25 \mathrm{mM} \mathrm{NH} \mathrm{HCO}_{3}$ and again for 1 minute in $100 \% \mathrm{ACN}$, dried, and rehydrated with $20 \mu \mathrm{L}$ of $20 \mathrm{ng} / \mu \mathrm{L}$ trypsin solution (Sequence Grade Modified; Promega) containing $25 \mathrm{mM} \mathrm{NH} \mathrm{HCO}_{3}$. The digestion was conducted overnight (18 hours) at $37^{\circ} \mathrm{C}$ and subsequently terminated by acidification with an equal volume of $2.5 \%$ trifluoroacetic acid (TFA). Peptides generated from the digestion were extracted with an equal volume of $0.1 \%$ TFA and vigorous vortexing for 15 minutes, followed by the addition of an identical volume of 70:25:5 ACN: $\mathrm{H}_{2} \mathrm{O}$ :TFA and repeated vortexing. The peptide solution was collected and dried completely in a Speed-Vac, resuspended in $50 \mu \mathrm{L}$ of $0.1 \%$ TFA, and solid phase extracted (ZipTip C18 pipette tips; Millipore). Peptides were eluted off the C18 column with 60:40:0.2 ACN: $\mathrm{H}_{2} \mathrm{O}$ :TFA directly onto 384-well plates (Opti-TOFApplied Biosystems) and recrystalized with $0.75 \mu \mathrm{L}$ of matrix $(10 \mathrm{mg} / \mathrm{mL} \alpha$-cyano-4-hydroxycinnamic acid in 50:35:0.1 acetone/CAN/TFA). Peptide map fingerprint result-dependent MS/MS analysis was then performed (4800 Matrix-Assisted Laser Desorption/Ionization-Time of Flight-Time of Flight [MALDI/TOF-TOF] mass spectrometer; Applied Biosystems). Peptide fingerprints were generated by scanning a 700- to 4000-Da mass range using 1000 shots acquired from 20 randomized regions of the sample spot at 3600 intensity of an on-axis laser in positive reflectron mode (OptiBeam; Applied Biosystems). The 10 most abundant precursors (excluding trypsin autolysis peptides and sodium/potassium adducts) were selected for subsequent tandem MS analysis, during which 2000 total shots were taken with 4200 laser intensity. Postsource decay (PSD) fragments from the precursors of interest were isolated by timed-ion selection and reaccelerated into the reflectron to generate the MS/MS spectrum. Raw data was deconvoluted (GPS Explorer software; Applied Biosystems) and submitted for peptide mapping and MS/MS ion search analysis against a nonredundant National Center for Biotechnology Information (NCBI; Bethesda, MD) database with an in-house licensed Mascot search engine (Matrix Science, London, UK).

\section{Results \\ Role of Serum-Free Medium Containing B27 Supplement in Primary Human RPE Culture Expansion and Maintenance}

Human prenatal RPE was dissected as isolated sheets (method 1) or RPE-choroid explants (method 2), chopped into $200-\mu \mathrm{m}$ sections, and placed in laminin-coated tissue culture plastic in serum-free RPE medium (SFRM) containing DMEM with high glucose, Ham's F12, and either B27 (SFRM-B27) or N2 (SFRMN2) supplement. B27 supplement was chosen for this study because it is commercially formulated and contains many constituents present in customized RPE medium preparations and/or deemed important for optimal RPE growth and maintenance (Table 2) ${ }^{6,8,12,18,30} \mathrm{~N} 2$ supplement, which contains a limited subset of factors present in $\mathrm{B} 27,{ }^{30,31}$ was used for comparison.

With either method, initial outgrowth of cells was observed in the presence of SFRM-B27 or SFRM-N2, but on subsequent passages, substantial culture expansion occurred with SFRMB27 only (Fig. 1). No cell expansion was seen with cultures maintained in SFRM without B27 or N2 (data not shown). The doubling time of these RPE cell cultures in SFRM-B27 over the first three passages was $1.84 \pm 0.30$ days $(n=4)$, and growth could be maintained for a maximum of six passages over 3 to 4 weeks, producing an approximately 40,000-fold increase in the number of cells. After passaging and plating at a density of 50,000 cells $/ \mathrm{cm}^{2}$, the cells became confluent within 5 days, adopted a characteristic RPE morphology, and became increas-

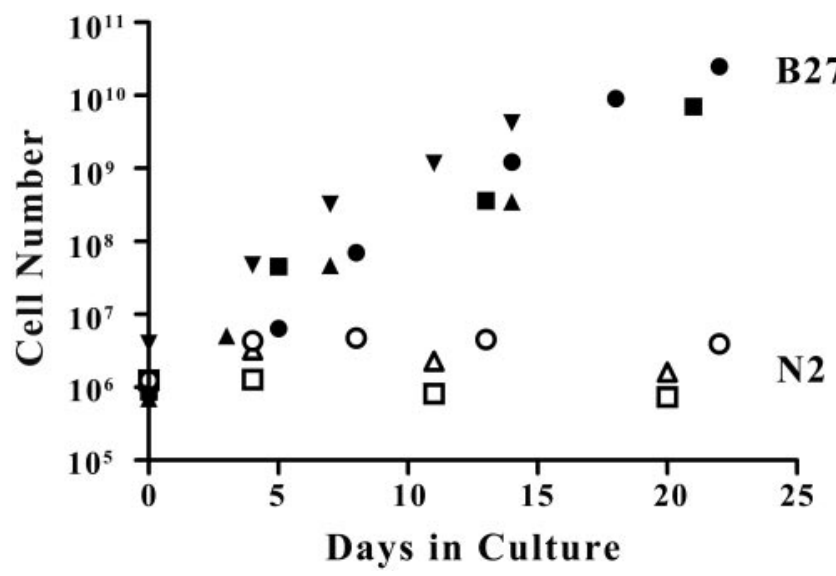

FIGURE 1. Growth potential of representative RPE cultures in serumfree medium containing either B27 (filled symbols) or N2 (open symbols) supplement. Cultures were derived from isolated RPE sheets (method 1 ; circles), RPE-choroid explants (method 2 ; squares) or first (up triangles) or second (down triangles) platings of pigmented spheroids (method 3). Data points reflect cumulative cell counts obtained after each culture passage. 

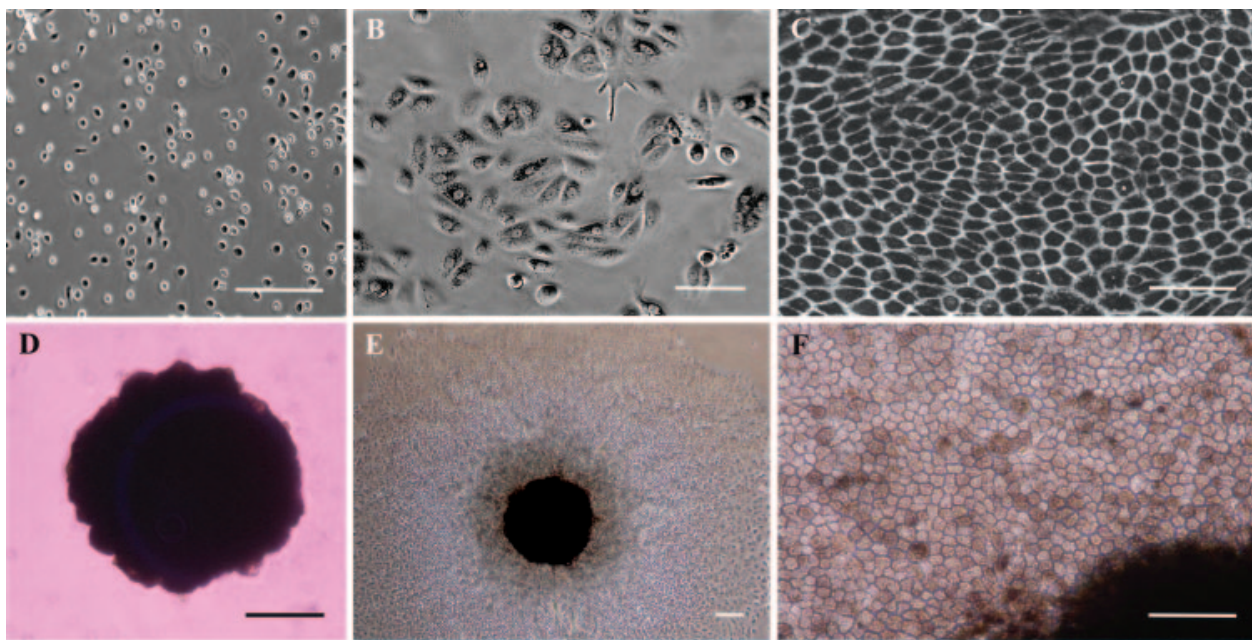

Figure 2. Phase-contrast light microscopic images of cultured RPE established from isolated sheets of primary tissue (method 1 ) on days 0 (A), 1 (B), and 28 (C) after third passage in SFRM-B27. (D) A typical pigmented spheroid (method 3) derived from sectioned RPE-choroid sheets after 25 days in suspension culture in SFRM-B27. (E) Low- and (F) highpower images of the same spheroid shown in (D) 6 days after attachment to laminin-coated tissue culture plastic. (G) Low- and (H) high-power images of a T-12.5 flask containing third-passage RPE (method 3) 6 weeks after seeding. Scale bars: (B C, H) $20 \mu \mathrm{m} ;(\mathbf{A}, \mathbf{F}) 50 \mu \mathrm{m} ;(\mathbf{D}, \mathbf{E})$ $200 \mu \mathrm{m}$.
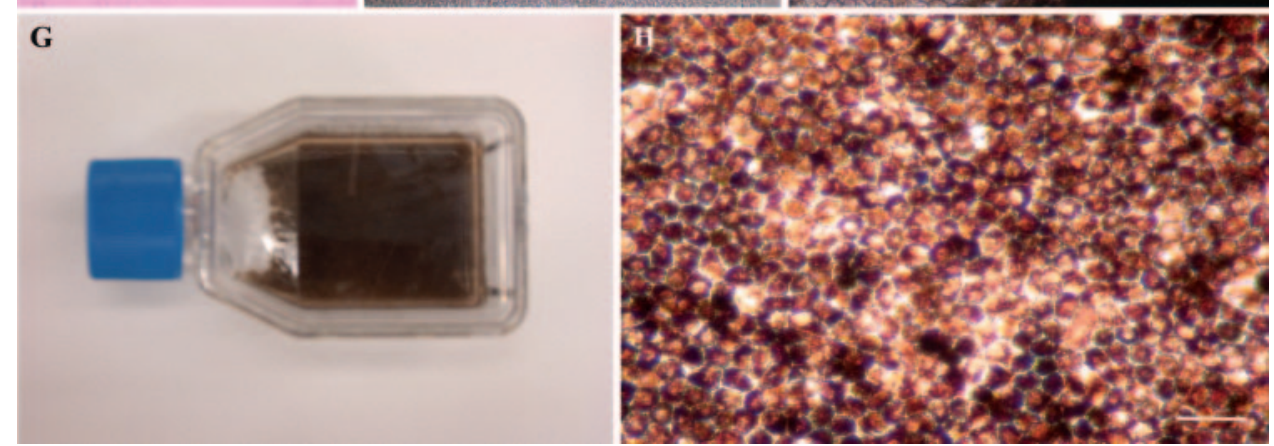

ingly compacted and pigmented over the ensuing 6 weeks (Figs. 2A-C). RPE monolayers were difficult to dissociate at this late stage and could not be expanded further.

Although similar growth characteristics were observed in RPE cultures established using method 1 or 2 , disadvantages were also encountered with both approaches. In method 1 , chopped sections of isolated, primary RPE would frequently fail to adhere to the laminin-coated plastic, while in method 2 , contaminating choroidal cell colonies (distinguished by their fibroblast morphology and tendency to form multilayers ${ }^{10}$ ) or mixed choroidal/RPE cell colonies were regularly seen after initial plating (Supplementary Fig. S1A; supplementary figures are online at http://www.iovs.org/cgi/content/full/49/2/788/ DC1). When present, these contaminating colonies required manual removal from culture flasks before subsequent passaging. Therefore, in an effort to promote primary tissue adherence and minimize early choroidal cell infiltration, a modification of method 2 was used. In this third method, dissected RPE-choroid explants were first grown as suspended spheroids in SFRM-B27 until most of them adopted a uniform, darkly pigmented appearance (Fig. 2D). Often, light microscopy could clearly identify a continuous surface layer of RPE on these spheroids (Supplementary Figure S1B). The pigmented spheroids readily adhered to laminin-coated tissue culture plastic and gave rise to rapidly enlarging monolayers of RPE cells with rare choroidal cell contamination (Figs. 2E, 2F). RPE cells generated in this manner could be dissociated, expanded and used to establish long-term monolayer cultures in T-12.5, -25, and -75 flasks (Figs. 2G, 2H; Supplementary Figs. S1C, S1D). Furthermore, the doubling time (1.59 \pm 0.14 days; $n=3$ ) and morphology of cell cultures established from pigmented spheroids (method 3) were essentially indistinguishable from those originally obtained from isolated RPE sheets (method 1) or RPE-choroid explants (method 2). Pigmented spheroids recovered after initial plating could be stored frozen or replated at least three times, to establish additional RPE cultures as needed. RPE cultures generated from reused spheroids retained similar growth characteristics (Fig. 1) and morphologic features (Supplementary Figs. S1E, S1F) exhibited by spheroids after initial plating. Based on these collective findings, we elected to use RPE cultures established by method 3 for subsequent experiments, except where otherwise indicated.

\section{Enhancement of RPE Proliferation by the Addition of FGF2}

Previous reports suggested that the inclusion of FGF2, a mitogen not present in B27 supplement, could significantly improve cell proliferation in serum-containing RPE cultures. ${ }^{17,34}$ This finding prompted Tezel and Del Priore ${ }^{12}$ to include FGF2 in their serum-free RPE culture medium preparation (Table 2). To determine whether the addition of FGF2 to SFRM-B27 could enhance RPE cell division compared with SFRM-B27 alone, 24-hour BrdU incorporation was measured in the presence or absence of FGF2 beginning 2 days after culture passage (a period corresponding to peak cell proliferation). Cultures ( $n=$ 3) maintained in SFRM-B27 with $20 \mathrm{ng} / \mathrm{mL}$ FGF2 demonstrated $37.8 \% \pm 2.8 \% \mathrm{BrdU}$ incorporation, compared with $19.6 \% \pm$ $2.6 \%$ in parallel cultures grown without FGF2 $(P=0.003$; Fig. 3 ). Thus, although SFRM-B27 is capable of supporting substantial human RPE growth in vitro, its proliferative effects can be augmented with the addition of one or more defined factors.

\section{Expression of RPE-Selective Genes and Proteins in Serum-Free Culture}

RT-PCR was used to examine the gene-expression profile of RPE monolayers $(n=3)$ grown and maintained exclusively in SFRM-B27. Complementary DNA was generated from longterm RPE monolayer cultures, all of which expressed the RPE- 


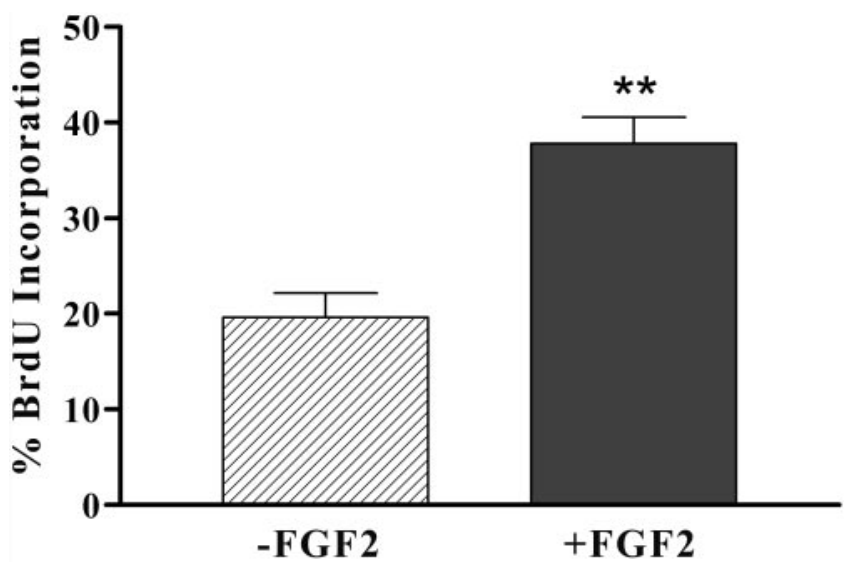

FIGURE 3. Percentage of BrdU incorporation into RPE cultured in SFRM-B27 without (batched bar) or with (solid bar) 20 ng/mL FGF2. Results are expressed as the mean \pm SEM of results of four experiments on three separate cultures (*** $P<0.005)$.

specific gene RPE65, as well as bestrophin, cellular retinaldehyde-binding protein $(C R A L B P)$, and receptor tyrosine kinase Mer (MerTK), whereas von Willebrand factor, an endothelial cell marker, was absent (Fig. 4A). PCR results obtained from cultures established by using method 1 or 2 showed the same pattern of gene expression (data not shown). Quantitative PCR analysis further demonstrated $<2$-fold variations in bestrophin gene expression levels across multiple cultures $(n=5)$ of different methods of origin, age in culture, passage number, and spheroid plating number (Supplementary Fig. S2).

Western blot analysis performed on cell lysates obtained from RPE monolayer cultures $(n=3)$ revealed protein expression of RPE65, bestrophin, and CRALBP in all samples (Fig. 4B). Other RPE proteins prominently expressed in vivo were also present in cell lysates, including ezrin and the tight junction proteins claudin-10 and occludin (Fig. 4B). Of note, occludin was often found in a low-molecular-weight form, although higher-molecular-weight forms indicative of protein phosphorylation ${ }^{35-37}$ were also present on these blots.

\section{Apical-Basal Polarity and Tight Junction Protein Expression in RPE Cells in Serum-Free Culture}

RPE cells are polarized in vivo, with their apical surface directed toward the outer segments of photoreceptors and their basal surface facing the choriocapillaris. ${ }^{1,6,8,38}$ This orientation is necessary for the RPE layer to perform many of its functions properly in vivo, including photopigment recycling, outer segment phagocytosis, ion and fluid transport, and directed factor secretion. ${ }^{1}$ To assess the polarity of cultured RPE cells grown and maintained in SFRM-B27, we performed immunocytochemistry and confocal microscopy using antibodies directed against RPE proteins expressed in the apical cell membrane (ezrin), in the basolateral membrane (bestrophin), or within the cytoplasm (CRALBP and RPE65). As shown in Figures $5 \mathrm{~A}-\mathrm{D}$, these proteins were predominantly localized to their expected regions within the cultured RPE cells.

Another important structural feature of native RPE monolayers is the existence of tight junctions between adjacent cells, which are key components of the outer blood-retina barrier. ${ }^{38}$ We investigated the expression and localization of the tight junction proteins zonula occludens (ZO)-1 and occludin, both of which demonstrated localized intercellular staining (Figs. 5E, 5F). A third junctional complex protein, claudin10 , was not consistently detected in the intercellular space by immunocytochemistry (data not shown). Together, these re- sults reveal that SFRM-B27 can support the development and maintenance of proper RPE cell orientation, as well as the expression and localization of some, but probably not all, of the tight junction proteins found in native RPE.

\section{Multiple Protein Factors Secreted by RPE Cells in Serum-Free Culture}

RPE cells secrete numerous growth factors and other proteins that impact photoreceptor health and function. ${ }^{1,4,6,11}$ The capacity of serum-free RPE monolayer cultures to produce and secrete specific growth factors was investigated by RT-PCR, Western blot analysis, and ELISA. First, we examined gene expression of a host of growth factor genes known to be expressed in the RPE, including pigment epithelium-derived growth factor $(P E D F)$, nerve growth factor $(N G F)$, insulin-like growth factor 1 (IGF1), vascular endothelial growth factor $(V E G F)$, epidermal growth factor $(E G F), \mathrm{FGF} 2$, transforming growth factor $\beta 1$ (TGFB1), and brain-derived growth factor (BDNF; Fig. 6A). These genes were expressed in our standard serum-free conditions in all cultures tested $(n=3)$. To determine whether selected growth factor gene transcripts are subsequently translated and released, CM was collected from these

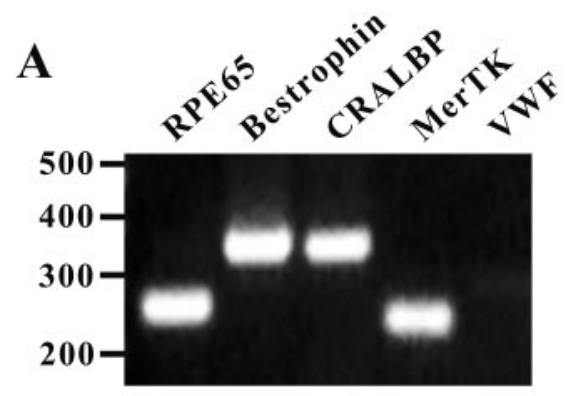

B
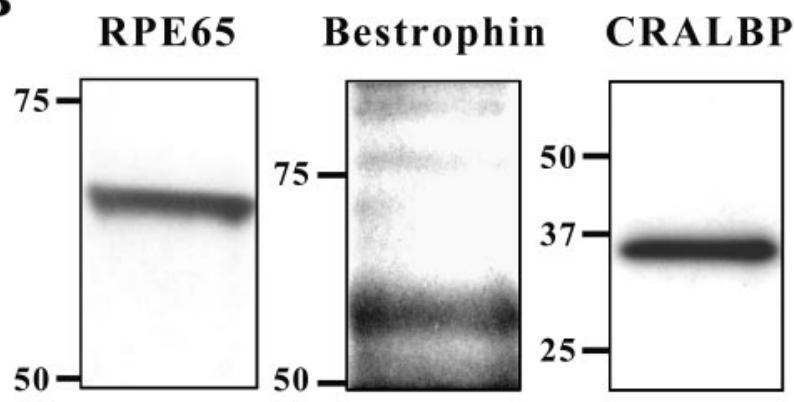

Ezrin
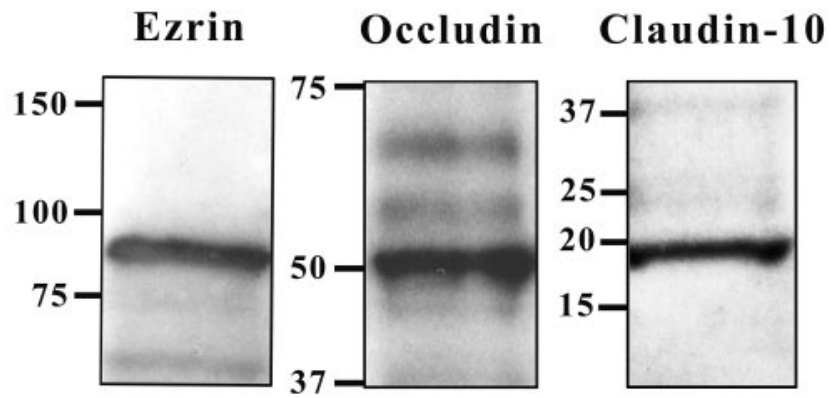

FIGURE 4. Expression of characteristic RPE genes (A) and proteins (B) in serum-free cultures as determined by RT-PCR and Western blot analysis ( $n \geq 3$ ), respectively. VWF was used as a marker for endothelial cell contamination. Results were consistent across all cultures tested, regardless of the method of origin (methods 1-3), time spent in culture (2-12 months), or number of passages (2-5). 

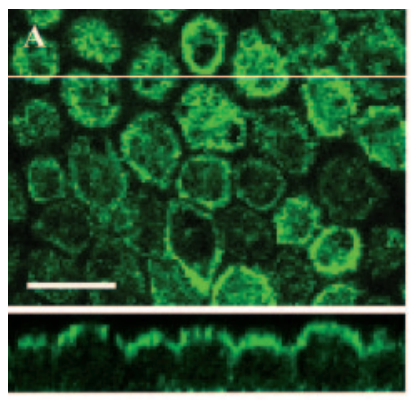

FIGURE 5. Immunocytochemistry staining and confocal imaging of RPE cultures (passage 2 or 3 ) grown exclusively in SFRM-B27. Top: an en face view of an RPE monolayer presented as a maximum-intensity projection through the $z$-axis. Bottom: cross-section through the $z$-plane of multiple optical slices at the location indicated by the white reference line in the corresponding top portion. Ezrin (A), CRALBP (B), RPE65 (C), bestrophin (D), occludin (E), and ZO-1 (F). Scale bar, $10 \mu \mathrm{m}$.

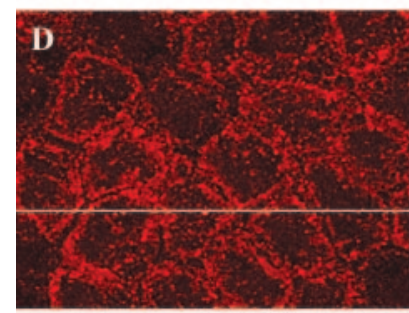

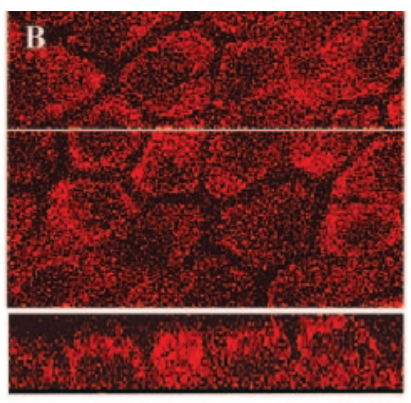
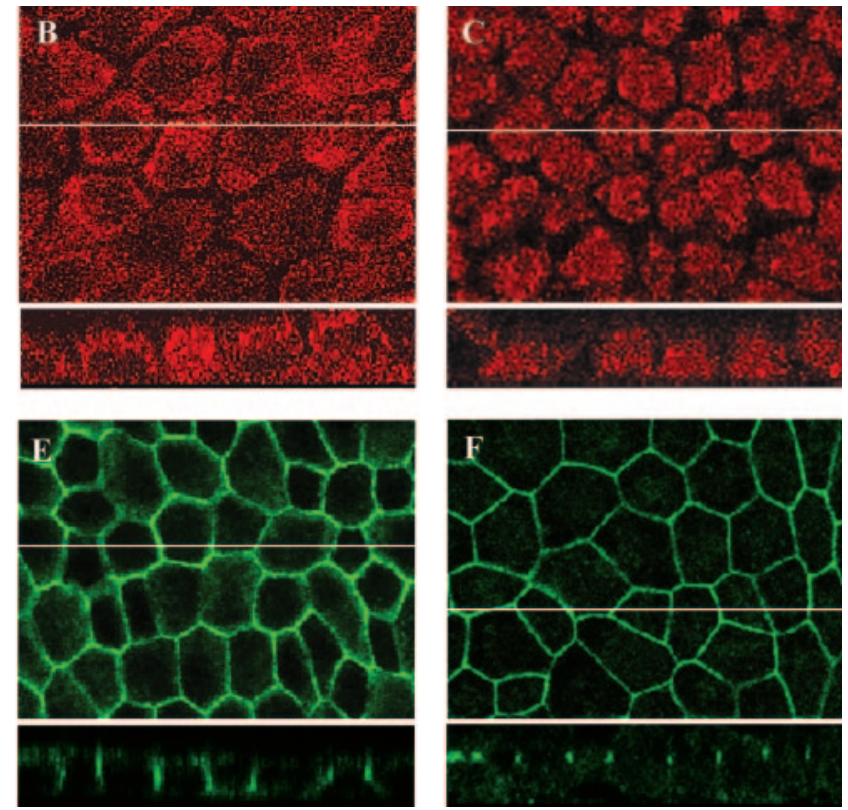

RPE monolayers, concentrated, and analyzed by Western blot $(n=3)$. All growth factors examined (PEDF, VEGF, and FGF2) were present in RPE CM (Fig. 6B). Quantification of PEDF, VEGF, and FGF 2 in RPE CM by ELISA ( $n \geq 3$ ) revealed secretion rates of $2453 \pm 1099 \mathrm{ng} / 10^{6}$ cells $/ \mathrm{d}, 0.94 \pm 0.05 \mathrm{ng} / 10^{6}$ cells/d, and $0.054 \pm 0.005 \mathrm{ng} / 10^{6}$ cells/d, respectively (Fig. 6C).

In addition to growth factors, RPE cells release a host of regulatory proteins with diverse functions into their surrounding microenvironment. ${ }^{11}$ The defined, serum-free medium used for this study allowed straightforward identification of major proteins present in the human RPE secretome. Concentrated RPE CM was separated by 2-D gel electrophoresis, and isolated protein spots were subjected to tandem mass spectrometry. We identified the 12 most abundant proteins in RPE $\mathrm{CM}$ by this method, including proteins involved in signaling, metal binding, and immune regulation, in addition to one carry-over from B27 supplement (bovine serum albumin; Table 3). Thus, cultured RPE retains a strong capacity to secrete a variety of factors without the need for serum supplementation.

\section{Discussion}

Numerous culture methods and media preparations have been described that support the initial attachment, limited growth, and long-term maintenance of primary human RPE cells in vitro. Early media formulations were relatively simple, primarily using a base medium supplemented with a high percentage of serum. ${ }^{22,23,39-43}$ A drawback of using serum supplementation in culture media is the ambiguous introduction of signaling molecules, including hormones and cytokines, and other known and unknown factors with the potential to influence cell behavior. ${ }^{12,13,44}$ With the development of more complex and precise RPE media preparations, less reliance was placed on undefined additives. ${ }^{6,8,18,45}$ Some of these tailored medium recipes called for the presence of a low percentage (1\%-5\%) of animal serum and/or tissue extract throughout the culture period, ${ }^{6,8}$ whereas in others, high levels of serum $(15 \%-20 \%)$ were present at initial seeding. ${ }^{6,18}$ By contrast, Tezel and Del Priore $^{12}$ developed a chemically defined culture medium that supported attachment, proliferation, and three serial passages of adult human RPE in the total absence of serum. However, characterization of the cultured RPE cells was limited to mor- phology and cytokeratin expression, and preparation of the customized serum-free medium required assembly of 12 separate components (including 7 growth factors and hormones) in addition to the base medium.

Comparison of the formulas used in successful low or no serum medium preparations for human RPE cultures reveals certain commonalities. All include a base medium (typically MEM or DMEM supplemented with amino acids and inorganic salts), transferrin and insulin, and most contain corticosteroid, triiodothyronine, selenium, and putrescine..$^{6,8,12,18}$ Many of these factors are necessary for the growth and maintenance of mammalian cells in general. Others, such as triiodothyronine and corticosteroid, are potentially important for RPE cell metabolism, fluid flux, and tight junction formation. ${ }^{46-48}$ Additional factors used in various RPE-specific media include EGF, FGF2, follicle stimulating hormone, retinoic acid, linoleic acid, ascorbic acid, progesterone, and taurine. These factors have been shown to affect RPE cell adhesion, proliferation, survival, and morphology, along with other critical cellular functions. ${ }^{12,17,18,49-51}$ Most of these substances are present in B27 supplement, a highly augmented form of N2 initially designed to support the maintenance of hippocampal neurons and neuronal cell lines. ${ }^{52}$ Subsequently, B27 was found to promote expansion of embryonic and adult neural stem cells in serumfree neurosphere cultures. ${ }^{30,53}$ Given its composition and proven efficacy in serum-free cultures of other neuroectodermal cell types, we predicted that B27 would also support RPE growth and long-term survival. However, the fact that B27 alone could eliminate the need for serum to establish and expand RPE cultures was unanticipated, since certain mitogens absent from B27 are often used to promote cell growth in other serum-free media preparations. ${ }^{12,18,32,33}$ Even so, mitogens can be used to enhance the growth potential of human RPE in SFRM-B27, as demonstrated by the increased cell proliferation observed after addition of FGF2. The effects of FGF2 supplementation on other aspects of RPE cell culture (e.g., differentiation) are currently being investigated by using our serumfree system.

In the present study, a single medium was used for all phases of RPE culture. Other culture systems use different formulations for the adherence, expansion, differentiation and/or maintenance of RPE cells in vitro. ${ }^{6,8}$ Phenotypic maturation of RPE monolayers in SFRM-B27, on the other hand, 


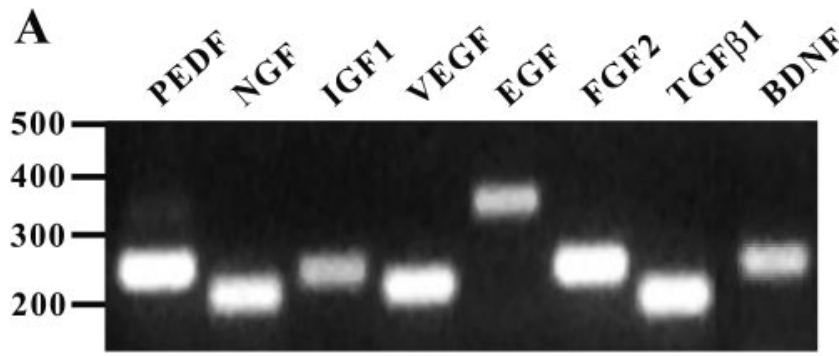

B

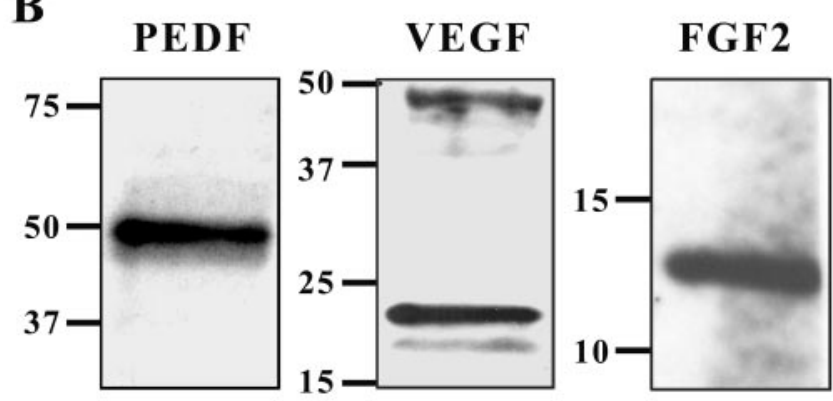

C

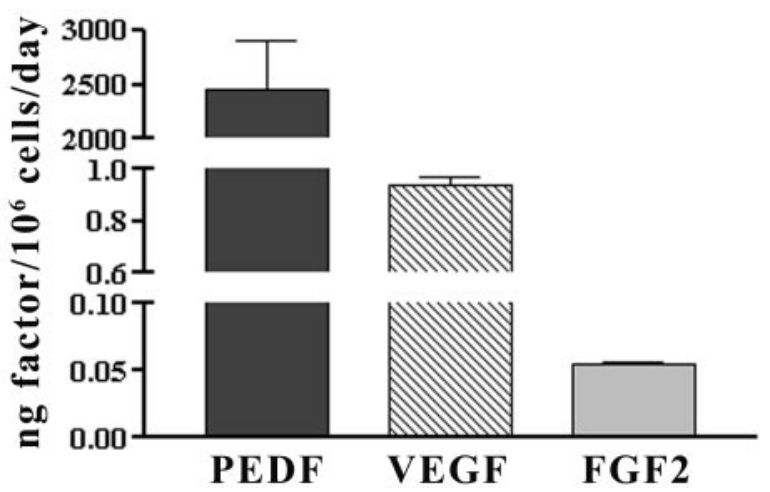

FIGURE 6. (A) Expression of selected growth factor genes in serumfree RPE cultures as determined by RT-PCR. (B) Western blot analysis of conditioned medium from serum-free RPE cultures reveal the presence of secreted growth factors. (C) Quantification of PEDF, VEGF, and FGF2 levels in serum-free RPE conditioned medium. Results were consistent across all cultures tested ( $n \geq 3$ ), regardless of method of origin (methods 1-3), time spent in culture (2-12 months), or the number of passages (2-5).

occurred spontaneously over time after the cells reached confluence, as evidenced by replicative senescence, adoption of a compact, polygonal morphology, and repigmentation.

The profound difference in growth potential between serum-free RPE cultures treated with B27 versus N2 supplement may prove useful in the identification of candidate factors important for RPE proliferation. There are 15 B27 components lacking in N2 supplement, five of which (triiodothyronine, vitamin A derivative, corticosteroid, selenium, and linoleic acid) were also incorporated in the serum-free RPE medium developed by Tezel and del Priore. ${ }^{12}$ The availability of defined, serum-free RPE culture protocols should facilitate the future investigation of the roles of these and other factors in human RPE growth.

Although SFRM-B27 supported RPE growth from isolated sheets of human RPE (method 1) or RPE-choroid explants (method 2), there were technical limitations to each of these approaches. Primary attachment was inconsistent with isolated RPE sheets, and early choroidal contamination was seen in explant cultures by light microscopy. However, we noted that chopped RPE-choroid explants that did not immediately plate down would persist as suspended spheroids in SFRM-B27 and become uniformly pigmented over time. Conversely, nonadherent RPE sheets degraded in culture, consistent with previous reports. ${ }^{54,55}$ Over time, the explant-derived, pigmented spheroids spontaneously attached to the culture plastic surface and cells of a nearly exclusive RPE morphology emanated from them. We postulate that the relative lack of choroidal contamination in these cultures is due to the development of a layer of RPE cells on the spheroid surface, which may sequester choroidal fibroblasts from substrate after plating. Electron microscopic studies are currently under way to investigate this possibility in more depth. RPE monolayers established from the pigmented spheroid method (method 3 ) could be passaged and expanded in a manner identical with those established from isolated RPE sheets or RPE-choroid explants. These findings were similar to those of Aronson, ${ }^{21}$ who first noted that rounded RPE-choroid fragments could generate RPE cultures after plating. Later, Rezai et al. ${ }^{54}$ and Gabrielian et al. ${ }^{56}$ showed that human fetal RPE could be grown on free-floating spheroidal polymer scaffolds in medium containing 15\% FBS. After attachment of the RPE-coated polymer spheres to culture plastic, RPE cells proliferated from the site of adhesion and formed monolayers. Therefore, culturing primary RPE initially as suspended spheroids on a natural (choroid) or synthetic substrate promotes subsequent cell attachment and proliferation in the absence or presence of serum, respectively.

Once grown to confluence in SFRM-B27, monolayer RPE cultures expressed markers indicative of mature RPE cells. Furthermore, immunocytochemical analysis revealed that the normal apical-basal polarity of RPE cells was preserved, along with the expression of characteristic junctional complex proteins. An exception was claudin-10, a tight junction protein shown to be expressed discontinuously by human RPE cultured in the presence of serum. ${ }^{6}$ In the present study, claudin-10 was detected in RPE lysates by Western blot but could not be unequivocally localized to the junctional complex by immunocytochemistry. Occludin expression also did not appear to be restricted to apical junctions, although it was clearly present along the lateral RPE membranes. A possible explanation for these observations is that SFRM-B27 lacks the elements necessary to assemble the complete complex. However, tight junction formation in cultured RPE cells can also be inhibited by serum, ${ }^{57}$ suggesting that multiple unknown factors, both positive and negative, can influence this process. ${ }^{58}$ The existence of serum-free RPE culture protocols should facilitate the search for these and other factors involved in the development and regulation of RPE structure and function in vitro.

A defined, serum-free environment is also conducive, although not essential, to the study of cellular secretion in vitro. Recently, An et al. ${ }^{11}$ examined the secretome profile of adult human RPE cultured in the presence of serum by labeling newly synthesized proteins with isotope-tagged amino acids. The authors detected a wide range of proteins in spent RPE medium, most of which are known to be secreted. In the present study, numerous discrete protein spots were visible after 2-D gel electrophoresis of concentrated RPE CM from serum-free prenatal cultures. Mass spectrometric analysis of the major protein spots subsequently led to the identification of 12 individual proteins. Six of these were also found in the study by An et al. ${ }^{11}$ : PEDF, galectin-3 binding protein, prostaglandin D2 synthase, complement subcomponents $1 \mathrm{~s}$ and $1 \mathrm{r}$, and $\beta$-actin. Of the remaining six prominent proteins, four are known to be produced by RPE (cystatin C, transthyretin, cathepsin D, and ceruloplasmin), whereas the ocular expression of another (alcadein $\alpha$-1) has not been documented. The final identified constituent in our study, bovine serum albumin, represents a 
TABLE 3. Proteins Identified by Mass Spectrometry in the Conditioned Medium of Serum-Free RPE Cultures

\begin{tabular}{|c|c|c|c|c|c|}
\hline Protein & $\begin{array}{c}\text { Accession } \\
\text { Number }\end{array}$ & $\begin{array}{l}\text { Mass } \\
(\mathbf{k D a})\end{array}$ & pI & $\begin{array}{l}\text { Mascot } \\
\text { Score* }\end{array}$ & $\begin{array}{c}\text { Protein } \\
\text { Coverage } \\
(\%)\end{array}$ \\
\hline Cystatin C & gi 73535286 & 13.3 & 8.75 & 485 & 66 \\
\hline Transthyretin & gi 1181953 & 13.8 & 5.55 & 549 & 80 \\
\hline Prostaglandin D2 synthase & gi 55962673 & 21.0 & 7.66 & 196 & 47 \\
\hline$\beta$-Actin & gi 14250401 & 41.0 & 5.56 & 376 & 44 \\
\hline Cathepsin D & gi 16740920 & 44.5 & 6.10 & 141 & 31 \\
\hline Pigment epithelium-derived factor & gi 30585311 & 46.4 & 5.97 & 502 & 40 \\
\hline Galectin-3 binding protein & gi 16041761 & 65.3 & 5.13 & 303 & 19 \\
\hline Albumin [Bos taurus] & gi 162648 & 69.2 & 5.82 & 364 & 37 \\
\hline Complement component 1 , s subcomponent & gi 34785163 & 76.6 & 4.86 & 174 & 21 \\
\hline Complement component $1, \mathrm{r}$ subcomponent & gi 62896521 & 80.2 & 5.89 & 112 & 18 \\
\hline Alcadein $\alpha-1$ & gi 54125663 & 108.6 & 4.83 & 383 & 22 \\
\hline Ceruloplasmin & gi 1942284 & 120.0 & 5.41 & 287 & 24 \\
\hline
\end{tabular}

${ }^{*}$ Mascot scores greater than 78 are significant $(P<0.05)$.

carry-over contaminant from B27 supplement. This finding is consistent with an earlier report in which serum contaminants were present in RPE CM despite multiple washings and incubation with serum-free medium before sample collection. ${ }^{11}$ Thus, short-term removal of serum from RPE culture medium is not sufficient to eliminate serum components in subsequent experiments.

Most of the proteins identified by our mass spectrometric analysis are secreted and have the potential to influence retinal development, homeostasis, and/or disease. PEDF is an inhibitor of retinal angiogenesis ${ }^{59,60}$ with neuroprotective and neurotrophic properties ${ }^{60}$ that is secreted by RPE before and after birth. ${ }^{61,62}$ Galectin-3 binding protein is apically secreted and promotes integrin-mediated cell adhesion and binds numerous extracellular proteins, including fibronectin. ${ }^{63,64}$ Prostaglandin D2 synthase, an enzyme postulated to function as a retinoid transporter, ${ }^{65}$ is released into the interphotoreceptor matrix where it is taken up by photoreceptors. The roles of complement proteins $\mathrm{C} 1 \mathrm{~s}$ and $\mathrm{C} 1 \mathrm{r}$ are less clear, although other complement proteins have been implicated in the pathogenesis of age-related macular degeneration (AMD). ${ }^{66,67}$ Cystatin C is a secreted cysteine protease inhibitor thought to be involved in neurodegeneration, neuroprotection, and central nervous system (CNS) repair. ${ }^{68,69}$ It is highly expressed in fetal and adult RPE and is postulated to regulate photoreceptor degradation during development and after trauma or ischemia. ${ }^{68,70-72}$ Cystatin C may indirectly regulate the activity of cathepsin D, a major lysosomal protease responsible for the degradation of phagocytosed photoreceptor outer segments. ${ }^{68,73}$ Although the proenzyme form of cathepsin D (52 $\mathrm{kDa}$ ) is secreted by RPE, ${ }^{74}$ its precise role after release into the extracellular environment is not known. Transthyretin is a homotetrameric serum transport protein for thyroxine and triiodothyronine that also interacts with retinol binding protein. ${ }^{75}$ In the eye, it is known to be secreted in abundance by RPE ${ }^{75}$ predominantly from the apical surface, ${ }^{76,77}$ but it is also found in AMD drusen deposits. ${ }^{78}$ Ceruloplasmin serves as an antioxidant, converting ferrous iron to the less dangerous ferric form. ${ }^{79,80}$ It has a secreted form that is present within the retina and vitreous, ${ }^{79-81}$ and the absence of ceruloplasmin has been linked to free radical injury and degenerative diseases within the brain and retina. ${ }^{79,82}$ Alcadeins indirectly associate with amyloid $\beta$-protein precursor (APP) ${ }^{83,84}$ and are thought to function physiologically in concert with APP, a molecule implicated in the pathogenesis of Alzheimer disease and AMD. ${ }^{85}$ Like APP, alcadein $\alpha-1$ is a transmembrane protein whose extracellular domain is subject to cleavage and release into the extracellular space. However, the present analysis discovered only the unprocessed form of alcadein $\alpha-1$ in RPE CM.
Although PEDF was the only growth factor identified as a major secreted protein by 2-D gel electrophoresis, RPE is known to secrete a host of other growth factors as well. ${ }^{1,4,60}$ It is likely that these other molecules are more labile than PEDF or are secreted at levels too low to detect on Coomassie- or silver-stained 2-D gels, even after concentration of RPE CM. However, the potential for serum-free RPE cultures to produce and secrete multiple growth factors, including VEGF and FGF2, was confirmed in this study by PCR, Western blot, and ELISA. Thus, human RPE cultured exclusively in SFRM-B27 retains its ability to secrete a host of growth factors implicated in the maintenance of retinal health and function.

Altogether, the results confirm that human RPE cultures can be established, expanded, and maintained in the complete absence of serum. By taking advantage of the commercially formulated B27 supplement, we simplified the preparation of serum-free medium without adversely affecting RPE cell morphology, protein expression, or secretory capacity. Additions to this minimal serum-free medium formulation or alterations in the culture technique may optimize the method further. However, the current protocol should facilitate examination of RPE development, structure, function, and disease in a defined, reproducible culture environment.

\section{Acknowledgments}

The authors thank Elizabeth Capowski and Jason Meyer for helpful comments during the preparation of the manuscript and Jolien Conner for assistance with confocal microscopy.

\section{References}

1. Strauss $O$. The retinal pigment epithelium in visual function. Physiol Rev. 2005;85:845-881.

2. Pearson RA, Dale N, Llaudet E, et al. ATP released via gap junction hemichannels from the pigment epithelium regulates neural retinal progenitor proliferation. Neuron. 2005;46:731-744.

3. Raymond SM, Jackson IJ. The retinal pigmented epithelium is required for development and maintenance of the mouse neural retina. Curr Biol. 1995;5:1286-1295.

4. Ishida K, Yoshimura N, Yoshida M, et al. Expression of neurotrophic factors in cultured human retinal pigment epithelial cells. Curr Eye Res. 1997;16:96-101.

5. Kuriyama S, Ohuchi T, Yoshimura N, et al. Growth factor-induced cytosolic calcium ion transients in cultured human retinal pigment epithelial cells. Invest Ophthalmol Vis Sci. 1991;32:2882-2890.

6. Maminishkis A, Chen S, Jalickee S, et al. Confluent monolayers of cultured human fetal retinal pigment epithelium exhibit morphology and physiology of native tissue. Invest Opbthalmol Vis Sci. 2006; $47: 3612-3624$ 
7. Engelmann K, Valtink M. RPE cell cultivation. Graefes Arch Clin Exp Ophthalmol. 2004;242:65-67.

8. Hu J, Bok D. A cell culture medium that supports the differentiation of human retinal pigment epithelium into functionally polarized monolayers. Mol Vis. 2001;7:14-19.

9. Marmorstein AD, Marmorstein LY, Rayborn M, et al. Bestrophin, the product of the Best vitelliform macular dystrophy gene (VMD2), localizes to the basolateral plasma membrane of the retinal pigment epithelium. Proc Natl Acad Sci USA. 2000;97: $12758-12763$.

10. McKay BS, Burke JM. Separation of phenotypically distinct subpopulations of cultured human retinal pigment epithelial cells. Exp Cell Res. 1994;213:85-92.

11. An E, Lu X, Flippin J, et al. Secreted proteome profiling in human RPE cell cultures derived from donors with age related macular degeneration and age matched healthy donors. J Proteome Res. 2006;5:2599-2610

12. Tezel TH, Del Priore LV. Serum-free media for culturing and serialpassaging of adult human retinal pigment epithelium. Exp Eye Res. 1998;66:807-815.

13. Shah G. Why do we still use serum in the production of biopharmaceuticals? Dev Biol Stand. 1999;99:17-22.

14. Griffiths JB. Serum and growth factors in cell culture media: an introductory review. Dev Biol Stand. 1987;66:155-160.

15. Goldberg AM. Mechanisms of neurotoxicity as studied in tissue culture systems. Toxicology. 1980;17:201-208.

16. Arrindell EL, McKay BS, Jaffe GJ, et al. Modulation of potassium transport in cultured retinal pigment epithelium and retinal glial cells by serum and epidermal growth factor. Exp Cell Res. 1992; 203:192-197.

17. Song MK, Lui GM. Propagation of fetal human RPE cells: preservation of original culture morphology after serial passage. J Cell Physiol. 1990;143:196-203.

18. Oka MS, Landers RA, Bridges CD. A serum-free defined medium for retinal pigment epithelial cells. Exp Cell Res. 1984;154:537-547.

19. Gaur VP, Liu Y, Turner JE. RPE conditioned medium stimulates photoreceptor cell survival, neurite outgrowth and differentiation in vitro. Exp Eye Res. 1992;54:645-659.

20. de Pomerai DI, Gali MA. Influence of serum factors on the prevalence of "normal" and "foreign" differentiation pathways in cultures of chick embryo neuroretinal cells. J Embryol Exp Morphol. 1981;62:291-308.

21. Aronson JF. Human retinal pigment cell culture. In Vitro. 1983; 19:642-650.

22. Ishida M, Lui GM, Yamani A, et al. Culture of human retinal pigment epithelial cells from peripheral scleral flap biopsies. Curr Eye Res. 1998; 17:392-402.

23. Edwards RB. Culture of mammalian retinal pigment epithelium and neural retina. Methods Enzymol. 1982;81:39-43.

24. Kanuga N, Winton HL, Beauchene L, et al. Characterization of genetically modified human retinal pigment epithelial cells developed for in vitro and transplantation studies. Invest Ophthalmol Vis Sci. 2002;43:546-555.

25. Davis AA, Bernstein PS, Bok D, et al. A human retinal pigment epithelial cell line that retains epithelial characteristics after prolonged culture. Invest Ophthalmol Vis Sci. 1995;36:955-964.

26. Rambhatla L, Chiu CP, Glickman RD, et al. In vitro differentiation capacity of telomerase immortalized human RPE cells. Invest Ophthalmol Vis Sci. 2002;43:1622-1630.

27. Dunn KC, Aotaki-Keen AE, Putkey FR, et al. ARPE-19, a human retinal pigment epithelial cell line with differentiated properties. Exp Eye Res. 1996;62:155-169

28. Klimanskaya I, Hipp J, Rezai KA, et al. Derivation and comparative assessment of retinal pigment epithelium from human embryonic stem cells using transcriptomics. Cloning Stem Cells. 2004;6:217245.

29. Lund RD, Wang S, Klimanskaya I, et al. Human embryonic stem cell-derived cells rescue visual function in dystrophic RCS rats. Cloning Stem Cells. 2006;8:189-199.

30. Wachs FP, Couillard-Despres S, Engelhardt M, et al. High efficacy of clonal growth and expansion of adult neural stem cells. Lab Invest. 2003;83:949-962.
31. Bottenstein JE, Sato GH. Growth of a rat neuroblastoma cell line in serum-free supplemented medium. Proc Natl Acad Sci USA. 1979; 76:514-517.

32. Svendsen CN, ter Borg MG, Armstrong RJ, et al. A new method for the rapid and long term growth of human neural precursor cells. J Neurosci Methods. 1998;85:141-152.

33. Gamm DM, Nelson AD, Svendsen CN. Human retinal progenitor cells grown as neurospheres demonstrate time-dependent changes in neuronal and glial cell fate potential. Ann NY Acad Sci. 2005; 1049:107-117.

34. Schwegler JS, Knorz MC, Akkoyun I, et al. Basic, not acidic fibroblast growth factor stimulates proliferation of cultured human retinal pigment epithelial cells. Mol Vis. 1997;3:10.

35. Peng S, Rahner C, Rizzolo LJ. Apical and basal regulation of the permeability of the retinal pigment epithelium. Invest Ophthalmol Vis Sci. 2003; $44: 808-817$.

36. Hirase T, Staddon JM, Saitou M, et al. Occludin as a possible determinant of tight junction permeability in endothelial cells. J Cell Sci. 1997;110:1603-1613.

37. Williams CD, Rizzolo LJ. Remodeling of junctional complexes during the development of the outer blood-retinal barrier. Anat Rec. 1997;249:380-388

38. Rizzolo LJ. Development and role of tight junctions in the retinal pigment epithelium. Int Rev Cytol. 2007;258:195-234.

39. Boulton ME, Marshall J, Mellerio J. Human retinal pigment epithelial cells in tissue culture: a means of studying inherited retinal diseases. Birth Defects Orig Artic Ser. 1982;18:101-118.

40. Wong HC, Boulton M, McLeod D, et al. Retinal pigment epithelial cells in culture produce retinal vascular mitogens. Arch Ophthalmol. 1988;106:1439-1443.

41. Turksen K, Opas M, Kalnins VI. Cytoskeleton, adhesion, and extracellular matrix of fetal human retinal pigmented epithelial cells in culture. Ophthalmic Res. 1989;21:56-66.

42. Zheng J, Guo Y, Jing X, et al. Modification of isolation and culture of human retinal pigment epithelial cells (in Chinese). Yan Ke Xue Bao. 1999;15:187-190.

43. Topp KS, Bisla K, Saks ND, et al. Centripetal transport of herpes simplex virus in human retinal pigment epithelial cells in vitro. Neuroscience. 1996;71:1133-1144.

44. Tian J, Ishibashi $\mathrm{K}$, Honda $\mathrm{S}$, et al. The expression of native and cultured human retinal pigment epithelial cells grown in different culture conditions. Br J Ophthalmol. 2005;89:1510-1517.

45. Pfeffer BA, Clark VM, Flannery JG, et al. Membrane receptors for retinol-binding protein in cultured human retinal pigment epithelium. Invest Ophthalmol Vis Sci. 1986;27:1031-1040.

46. Lauber JK. Diurnal mitochondrial changes in avian retinal pigment epithelium: a search for correlation with thyroid state. Curr Eye Res. 1982;2:863-868, 1983

47. Heth CA, Yankauckas MA, Adamian M, et al. Characterization of retinal pigment epithelial cells cultured on microporous filters. Curr Eye Res. 1987;6:1007-1019.

48. Arndt C, Sari A, Ferre M, et al. Electrophysiological effects of corticosteroids on the retinal pigment epithelium. Invest Ophthalmol Vis Sci. 2001;42:472-475.

49. Campochiaro PA, Hackett SF, Conway BP. Retinoic acid promotes density-dependent growth arrest in human retinal pigment epithelial cells. Invest Ophthalmol Vis Sci. 1991;32:65-72.

50. van den Berg JJ, Cook NE, Tribble DL. Reinvestigation of the antioxidant properties of conjugated linoleic acid. Lipids. 1995; 30:599-605.

51. Kaven CW, Spraul CW, Zavazava NK, et al. Growth factor combinations modulate human retinal pigment epithelial cell proliferation. Curr Eye Res. 2000;20:480 - 487.

52. Brewer GJ, Torricelli JR, Evege EK, et al. Optimized survival of hippocampal neurons in B27-supplemented Neurobasal, a new serum-free medium combination. J Neurosci Res. 1993;35:567576.

53. Svendsen CN, Fawcett JW, Bentlage C, et al. Increased survival of rat EGF-generated CNS precursor cells using B27 supplemented medium. Exp Brain Res. 1995;102:407-414

54. Rezai KA, Farrokh-Siar L, Botz ML, et al. Biodegradable polymer film as a source for formation of human fetal retinal pigment 
epithelium spheroids. Invest Ophthalmol Vis Sci. 1999;40:12231228.

55. Tezel TH, Del Priore LV. Reattachment to a substrate prevents apoptosis of human retinal pigment epithelium. Graefes Arch Clin Exp Ophthalmol. 1997;235:41-47.

56. Gabrielian K, Oganesian A, Farrokh-Siar L, et al. Growth of human fetal retinal pigment epithelium as microspheres. Graefes Arch Clin Exp Ophthalmol. 1999;237:241-248.

57. Chang CW, Ye L, Defoe DM, et al. Serum inhibits tight junction formation in cultured pigment epithelial cells. Invest Ophthalmol Vis Sci. 1997;38:1082-1093.

58. Rahner C, Fukuhara M, Peng S, et al. The apical and basal environments of the retinal pigment epithelium regulate the maturation of tight junctions during development. J Cell Sci. 2004;117:33073318.

59. Dawson DW, Volpert OV, Gillis P, et al. Pigment epitheliumderived factor: a potent inhibitor of angiogenesis. Science. 1999; 285:245-248.

60. Barnstable CJ, Tombran-Tink J. Neuroprotective and antiangiogenic actions of PEDF in the eye: molecular targets and therapeutic potential. Prog Retin Eye Res. 2004;23:561-577.

61. Tombran-Tink J, Shivaram SM, Chader GJ, et al. Expression, secretion, and age-related downregulation of pigment epithelium-derived factor, a serpin with neurotrophic activity. J Neurosci. 1995; 15:4992-5003.

62. Behling KC, Surace EM, Bennett J. Pigment epithelium-derived factor expression in the developing mouse eye. Mol Vis. 2002;8: 449-454.

63. McFarlane S, Glenn JV, Lichanska AM, et al. Characterisation of the advanced glycation endproduct receptor complex in the retinal pigment epithelium. BrJ Ophthalmol. 2005;89:107-112.

64. Hughes RC. Secretion of the galectin family of mammalian carbohydrate-binding proteins. Biochim Biophys Acta. 1999;1473:172185.

65. Beuckmann CT, Gordon WC, Kanaoka Y, et al. Lipocalin-type prostaglandin D synthase (beta-trace) is located in pigment epithelial cells of rat retina and accumulates within interphotoreceptor matrix. J Neurosci. 1996;16:6119-6124.

66. Moshfeghi DM, Blumenkranz MS. Role of genetic factors and inflammation in age-related macular degeneration. Retina. 2007;27: $269-275$.

67. Sivaprasad S, Chong NV. The complement system and age-related macular degeneration. Eye. 2006;20:867-872.

68. Wasselius J, Hakansson K, Johansson K, et al. Identification and localization of retinal cystatin C. Invest Ophthalmol Vis Sci. 2001; 42:1901-1906.

69. Wakasugi K, Nakano T, Morishima I. Association of human neuroglobin with cystatin $\mathrm{C}$, a cysteine proteinase inhibitor. Biochemistry. 2004;43:5119-5125.
70. Paraoan L, Grierson I, Maden BE. Fate of cystatin C lacking the leader sequence in RPE cells. Exp Eye Res. 2003;76:753-756.

71. Zurdel J, Finckh U, Menzer G, et al. CST3 genotype associated with exudative age related macular degeneration. $\mathrm{Br} J$ Ophthalmol. 2002;86:214-219.

72. Paraoan L, Grierson I, Maden BE. Analysis of expressed sequence tags of retinal pigment epithelium: cystatin $\mathrm{C}$ is an abundant transcript. Int J Biochem Cell Biol. 2000;32:417-426.

73. Rakoczy PE, Sarks SH, Daw N, et al. Distribution of cathepsin D in human eyes with or without age-related maculopathy. Exp Eye Res. 1999;69:367-374.

74. Hoppe G, O'Neil J, Hoff HF, et al. Products of lipid peroxidation induce missorting of the principal lysosomal protease in retinal pigment epithelium. Biochim Biophys Acta. 2004;1689:33-41.

75. Pfeffer BA, Becerra SP, Borst DE, et al. Expression of transthyretin and retinol binding protein mRNAs and secretion of transthyretin by cultured monkey retinal pigment epithelium. Mol Vis. 2004;10: 23-30.

76. Ong DE, Davis JT, O'Day WT, et al. Synthesis and secretion of retinol-binding protein and transthyretin by cultured retinal pigment epithelium. Biochemistry. 1994;33:1835-1842.

77. Jaworowski A, Fang Z, Khong TF, et al. Protein synthesis and secretion by cultured retinal pigment epithelia. Biochim Biophys Acta. 1995;1245:121-129.

78. Mullins RF, Russell SR, Anderson DH, et al. Drusen associated with aging and age-related macular degeneration contain proteins common to extracellular deposits associated with atherosclerosis, elastosis, amyloidosis, and dense deposit disease. FASEB J. 2000;14: 835-846.

79. Hahn P, Qian Y, Dentchev T, et al. Disruption of ceruloplasmin and hephaestin in mice causes retinal iron overload and retinal degeneration with features of age-related macular degeneration. Proc Natl Acad Sci USA. 2004;101:13850-13855.

80. Hahn P, Dentchev T, Qian Y, et al. Immunolocalization and regulation of iron handling proteins ferritin and ferroportin in the retina. Mol Vis. 2004; 10:598-607.

81. Chen L, Dentchev T, Wong R, et al. Increased expression of ceruloplasmin in the retina following photic injury. Mol Vis. 2003; 9:151-158.

82. Vassiliev V, Harris ZL, Zatta P. Ceruloplasmin in neurodegenerative diseases. Brain Res Rev. 2005;49:633-640.

83. Araki Y, Miyagi N, Kato N, et al. Coordinated metabolism of alcadein and amyloid beta-protein precursor regulates FE65-dependent gene transactivation. J Biol Chem. 2004;279:24343-24354.

84. Araki Y, Tomita S, Yamaguchi $H$, et al. Novel cadherin-related membrane proteins, alcadeins, enhance the X11-like protein-mediated stabilization of amyloid beta-protein precursor metabolism. J Biol Chem. 2003;278:49448-49458.

85. Yoshida T, Ohno-Matsui K, Ichinose S, et al. The potential role of amyloid beta in the pathogenesis of age-related macular degeneration. J Clin Invest. 2005;115:2793-2800. 